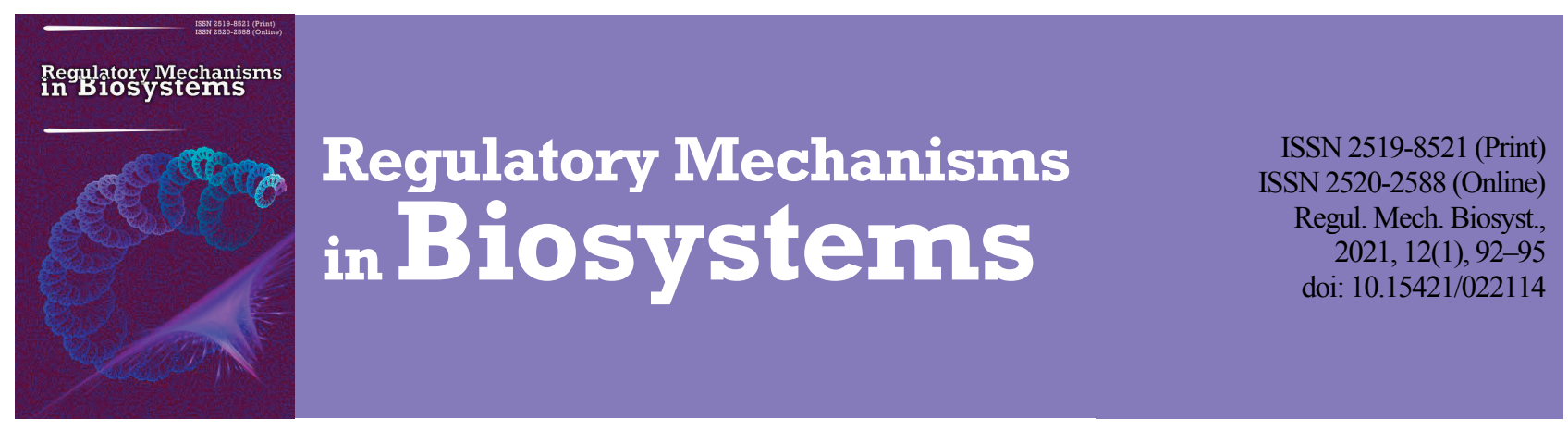

\title{
The effect of additives with essential oils on the productivity of young pigs
}

\author{
K. M. Syrovatko, V. S. Vuhliar \\ Vinnitsa National Agrarian University, Vinnitsia, Ukraine
}

Article info

Received 24.12.2020

Received in revised form 27.01.2021

Accepted 30.01.2021

Vinnitsa National

Agrarian University,

Sunnyst., 3,

Vinnitsia, 21008, Ukraine.

Tel.: +38-098-933-41-00.

E-mail:

vasja.vugljar@rambler.ru

\author{
Syrovatko, K. M., \& Vuhliar, V. S. (2021). The effect of additives with essential oils on the productivity of young pigs. Regulatory \\ Mechanisms in Biosystems, 12(1), 92-95. doi:10.15421/022114
}

Modern feed additives based on natural plant components are increasingly used as an alternative to synthetic antibiotics in animal nutrition. Phytobiotics are natural plant components that are increasingly gaining demand for use in ready-to-eat animal feed and provide proper health and microflora of the body. A scientific and economic experiment was conducted in order to determine their effect on the productivity of young pigs. We composed three groups of analogues each comprising 12 individuals, which were formed in a 15-day equalization period. According to the results of the study on the use of a new feed factor protein-vitamin-mineral supplement Efiprot in the diets of young pigs, a positive effect was observed on increase in the average daily weight gain by $4.1 \%$ and $7.1 \%$ compared with the control group. There was also seen a better absorption of nutrients in the diet compared with the control indicator. During inclusions of essential oil in the diet of the pigs, we observed an increase in the digestibility of nutrients: in particular, the level of digestibility of dry and organic matter increased in the second and third experimental groups, as well as digestible protein and digestibility of crude fat was better in the first experimental group than in the control group. During the study, there was a tendency towards better breakdown of sparingly soluble carbohydrates under the action of feed additives compared with the control indicator. Thus, the use of protein-vitamin-mineral supplement during the rearing of young pigs not only increased the efficiency of their rearing, but also led to better digestion and maintenance of the microflora of the gastrointestinal tract.

Keywords: fattening; average daily weight gains; protein-vitamin-mineral supplement; Efiprot; productivity; digestibility.

\section{Introduction}

Livestock in general and pig breeding in particular are operated successfully when a number of factors are in balance: growing, keeping, breeding, feeding, accounting, operational and managerial accounting and a number of decisions aimed at converting companies with extensive production to intensive production (Tymchenko et al., 2009). This requires a manifestation of the genetic potential of pig productivity, and this is possible only by ensuring biologically substantial feeding of animals (Babkov, 2016), balanced by all indicators of feed nutrition (Ibatullin et al., 2007; Ibatullin et al., 2015), energy, protein, fat, hygienic conditions appropriate to the physiological state of each production age group, and able to ensure maximum productivity and significantly reduce the cost of production of final products (Begma \& Mikityuk, 2011). Therefore, in order to satisfy the natural needs of the animal's body for nutrients and ensure high productivity, farms are increasingly applying substantial feeds (Svezhentsov et al., 2008). This type of feed contains a set of essential nutrients, minerals and biologically active substances that have a positive effect on animal productivity, equaling $20-25 \%$ on average, and at the same time reduces feed costs per unit of output (Velichko et al., 2004). Along with balanced feeding, it is also necessary to ensure the normal functioning of the gastrointestinal tract so that food is absorbed by the body (Kuzmenko et al., 2009). Therefore, to achieve this goal, the feed needs to be broken down under the influence of gastrointestinal juices to the state in which it would be absorbed by the wall of the gastrointestinal tract (Bilyavtseva, 2016). In pig breeding, feed enzymes, probiotics, prebiotics, acidifiers, phytase containing preparations and others are increasingly used to improve digestion and assimilation of feeds (as an alternative to antibiotics). They have a positive effect on the digestive system and inhibit the development of pathogenic bacteria and fungi (Kuzmenko et al., 2011; Kucheryavy et al., 2013). Some of the new components are phytogenic feed additives, which are increasingly used in diets to increase the efficiency of animal husbandry (Steiner \& Lokhov., 2011). Phytobiotic feed additives can control the intestinal microflora indirectly, supporting the internal defense mechanisms of the animal's body (Wei et al., 2020). Phytogenic supplements include herbal products that contain fructooligosaccharides, plant extracts and essential oils. They are extracted from herbs or spices with aromatic and functional properties that are beneficial to the animal (Windisch et al., 2008). The use of phytobiotic feed additives in the diet of farm animals and poultry is rationally substantiated and contributes to the refusal to use antibiotics in feed (Vuhliar, 2020). The objective of the study is to study the productivity, digestibility of nutrients in the diet, blood parameters of young pigs raised for meat when feeding a new PVMS (protein-vitamin mineral supplement) with essential oils.

\section{Materials and methods}

All the experiments were performed in compliance with the requirements of the European Convention for the Protection of Vertebrate Animals Used for Scientific Experiments or Other Scientific Purposes of 1986, as well as the Law of Ukraine "On Protection of Animals from Cruelty" as of 21.02.2006 No. 3447-IV.

The scientific and economic experiment was conducted at the basis of the Kordelivske State Enterprise of Kalynivka district of Vinnytsia Oblast. According to the method of the study, we composed three analogue pairs of young pigs of Large White breed, 12 individuals in each group. The piglets were selected at the age of 28 days, the average live weight at the beginning of the equalization period equaled $9.03,9.05$ and $9.04 \mathrm{~kg}$. After the 15-day equalization period for animals, appropriate study schemes were developed, and the growth intensity of the piglets that received different doses for the respective feeding phases was monitored. In the main period of the study, the animals were fed PVMS: starter, grower and 
finisher given in different doses. The control group consumed PVMS without the addition of essential oils. The second and third groups were fed with Efiprot PVMS with different doses (Table 1).

Table 1

The scheme of the experiment

\begin{tabular}{|c|c|c|c|c|}
\hline \multirow{2}{*}{\multicolumn{2}{|c|}{$\begin{array}{l}\text { Gro } \frac{\text { Equaling }}{8-15 \mathrm{~kg}} \\
\text { ups }\end{array}$}} & \multicolumn{3}{|c|}{ Main } \\
\hline & & $15-35 \mathrm{~kg}$ & $35-65 \mathrm{~kg}$ & $65-110 \mathrm{~kg}$ \\
\hline $\begin{array}{l}\text { Con } \\
\text { trol }\end{array}$ & $\begin{array}{l}\text { MD with } \\
\text { PVMS }\end{array}$ & $\begin{array}{c}\text { without } \\
\text { essential oils }\end{array}$ & $\begin{array}{c}\text { without } \\
\text { essential oils }\end{array}$ & $\begin{array}{c}\text { without } \\
\text { essential oils }\end{array}$ \\
\hline I & $\begin{array}{l}\text { MD with } \\
\text { PVMS }\end{array}$ & $\begin{array}{c}\text { Efiprot-starter, } \\
400 \mathrm{~g} / \mathrm{T} \text { of } \\
\text { essential oils }\end{array}$ & $\begin{array}{c}\text { Efiprot-grower, } \\
200 \mathrm{~g} / \mathrm{T} \text { of } \\
\text { essential oils }\end{array}$ & $\begin{array}{c}\text { Efiprot-finisher, } \\
150 \mathrm{~g} / \mathrm{T} \text { of } \\
\text { essential oils }\end{array}$ \\
\hline II & $\begin{array}{l}\text { MD with } \\
\text { PVMS }\end{array}$ & $\begin{array}{c}\text { Efiprot-starter, } \\
600 \mathrm{~g} / \mathrm{T} \text { of } \\
\text { essential oils }\end{array}$ & $\begin{array}{c}\text { Efiprot-grower, } \\
400 \mathrm{~g} / \mathrm{T} \text { of } \\
\text { essential oils }\end{array}$ & $\begin{array}{c}\text { Efiprot - finisher, } \\
200 \mathrm{~g} / \mathrm{T} \text { of } \\
\text { essential oils }\end{array}$ \\
\hline
\end{tabular}

Note: MD - the main diet, PVMS - protein-vitamin-mineral supplement.

The main diet consisted of a grain mixture of feed: barley and wheat, with different ratios for individual phases of feeding. The lack of certain nutrients in the diet was compensated by PVMS Efiprot, which contains thirty indicators, including 10 of mineral nature, 7 - proteins and 13 vitamins. Furthermore, the supplement contains antioxidants, flavorings, acidulent, multienzyme, probiotic and essential oils. Feeds were used in dry form, given twice a day. Watering was automated. The young pigs of the experimental group were kept in a typical pigsty in groups of 12 individuals. To determine the fattening qualities in young pigs, we used the following parameters: average daily weight gain, age of reaching the live weight of $100 \mathrm{~kg}$, and feed expenditure per $1 \mathrm{~kg}$ of growth.

Statistical processing of the obtained results was performed using the ANOVA program, the data in the tables are presented in the form of $\mathrm{x} \pm$ $\mathrm{SD}$ (mean \pm standard deviation). The difference was considered significant at $\mathrm{P}<0.05$ (taking into account the Bonferroni correction).

\section{Results}

When studying the effect of the new feed additive Efiprot with the content of essential oils of 150 and $200 \mathrm{~g}$ per 1 ton of feed, there was a positive product effect, an increase in live weight (Table 2). Therefore, introduction of the tested PVMS Efiprot to the diet of the second group in the main period with the concentration of $400,200,150$ caused increase in the average daily by $33 \mathrm{~g}$ or $4.1 \%(\mathrm{P}<0.05)$ and an absolute increase of $4.06 \mathrm{~g}$ or $4.04 \%(\mathrm{P}<0.05)$.

\section{Table 2}

The effect of essential oils in the doses of 400, 200, $150 \mathrm{~g} / \mathrm{T}$ and $600,400,200 \mathrm{~g} / \mathrm{T}$ of feed on productivity of young pigs for the main period of the experiment, being 127 days, from 15 to $110 \mathrm{~kg}$ of live weight $(\mathrm{x} \pm \mathrm{SD}, \mathrm{n}=12)$

\begin{tabular}{lccc}
\hline \multicolumn{1}{c}{ Indicator } & Control & I & II \\
\hline $\begin{array}{l}\text { Weight of one animal at the beginning } \\
\text { of the period, } \mathrm{kg}\end{array}$ & $15.90 \pm 0.21$ & $15.90 \pm 0.13$ & $15.85 \pm 0.16$ \\
Weight of one animal at the end & $112.3 \pm 1.4$ & $116.3 \pm 1.1^{*}$ & $119.5 \pm 1.6^{* *}$ \\
of the period, kg & $96.4 \pm 1.5$ & $100.4 \pm 1.1^{*}$ & $103.6 \pm 1.5^{* *}$ \\
Weight gain in live weight: absolute, $\mathrm{g}$ & $758 \pm 11$ & $791 \pm 9^{*}$ & $816 \pm 12^{* *}$ \\
$\begin{array}{l}\text { Average daily, g } \\
\text { Feed expenditures per kg of gain, EFU }\end{array}$ & 4.05 & 3.89 & 3.77 \\
\hline
\end{tabular}

Note: $*-\mathrm{P}<0.05, * *-\mathrm{P}<0.01, * * *-\mathrm{P}<0.001$ differences between the experimental and the control group; EFU - energy feed units.

Therefore, by the end of the period, the live weight increased by $4.05 \mathrm{~kg}$ or $3.48 \%(\mathrm{P}<0.05)$, while feed expenditures decreased by $3.95 \%$. Feeding the third experimental group of young pigs with PVMS Efiprot with $600,400,200 \mathrm{~g} / \mathrm{T}$ of essential oils, the tendency to increase as the daily average by $58 \mathrm{~g}(7.1 \%)(\mathrm{P}<0.01)$ and absolute weight gains of $7.23 \mathrm{~kg}(6.97 \%, \mathrm{P}<0.01)$. Live weight during this period increased by $7.18 \mathrm{~kg}(\mathrm{P}<0.01)$, and feed consumption decreased by $6.92 \%$. When using the new Efiprot PVMS, which contains plant processing products (essential oils), in feeding young pigs a positive productive effect was observed, and therefore the slaughter parameters increased (Table 2). Therefore, the slaughter weight, compared with the control, was higher in the second and third groups by 4.82 and $8.37 \mathrm{~kg}$, respectively. Slaughter yield increased by $3.47 \%$ and $4.37 \%$, respectively. Feeding PVMS also led to better parameters of carcass weight. In particular, there was $7.3 \mathrm{~kg}$ increase in the third group, and $4.3 \%$ in the second. These carcass yield exceeded the control by $3.19 \%$ in the second and by $3.99 \%$ in the third groups. These masses of offal did not have a significant difference between the groups and were at almost the same level. However, there was a tendency to some increase in their consumption when receiving the PVMS.

Table 3

The effect of essential oils in the doses of 400, 200, $150 \mathrm{~g} / \mathrm{T}$ and $600,400,200 \mathrm{~g} / \mathrm{T}$ of feed on slaughter weights of pigs $(\mathrm{x} \pm \mathrm{SD}, \mathrm{n}=3)$

\begin{tabular}{lrrc}
\hline \multicolumn{1}{c}{ Indicator } & \multicolumn{1}{c}{ Control } & I & II \\
\hline Pre-slaughter live weight, kg & $113.31 \pm 2.13$ & $114.32 \pm 1.47$ & $117.29 \pm 1.51$ \\
Slaughter weight, $\mathrm{kg}$ & $90.68 \pm 1.81$ & $95.50 \pm 1.94$ & $99.05 \pm 1.69^{*}$ \\
Slaughter yield, \% & $80.03 \pm 2.45$ & $83.53 \pm 0.62$ & $84.41 \pm 0.43$ \\
Carcass weight, kg & $74.30 \pm 1.55$ & $78.61 \pm 2.05$ & $81.63 \pm 1.57^{*}$ \\
Carcass yield, \% & $65.57 \pm 0.82$ & $68.76 \pm 1.08$ & $69.56 \pm 1.57$ \\
Head weight, kg & $6.73 \pm 0.22$ & $6.84 \pm 0.21$ & $7.13 \pm 0.73$ \\
Skin weight, kg & $6.82 \pm 0.24$ & $7.01 \pm 0.14$ & $7.06 \pm 0.54$ \\
Front leg, kg & $0.80 \pm 0.28$ & $0.83 \pm 0.07$ & $0.83 \pm 0.07$ \\
Hind leg, kg & $0.93 \pm 0.11$ & $0.96 \pm 0.13$ & $1.03 \pm 0.08$ \\
Internal fat, kg: & $1.14 \pm 0.12$ & $1.22 \pm 0.28$ & $1.40 \pm 0.26$ \\
On the neck, kg & $2.16 \pm 0.89$ & $2.66 \pm 0.54$ & $2.33 \pm 0.40$ \\
On the withers, $\mathrm{kg}$ & $3.17 \pm 0.54$ & $3.50 \pm 0.35$ & $2.66 \pm 0.54$ \\
On the waist, kg & $2.16 \pm 0.89$ & $2.05 \pm 0.35$ & $2.83 \pm 0.54$ \\
On the crosses, $\mathrm{kg}$ & $1.53 \pm 0.26$ & $1.83 \pm 0.28$ & $2.48 \pm 0.86$ \\
Average, kg & $2.24 \pm 0.35$ & $2.49 \pm 0.46$ & $2.58 \pm 0.49$ \\
\hline
\end{tabular}

Note: see Table 2 .

Thickness of subcutaneous fatback of the experimental groups in different anatomical parts of the carcasses of slaughtered pigs was slightly higher than the average values of the control by $10.04-13.17 \%$ in the second and third groups. Therefore, feeding PVMS Efiprot led to a tendency to increase in its thickness in the second and third groups on the necks $18.79-7.29 \%$, buttocks $18.03-40.00 \%$, compared with the control. Parameters were higher by $9.43 \%$ for the withers in the second and by $23.67 \%$ for the waist in the third group. Analyzing the data, it is possible to draw the conclusion that the quality of the carcasses to some extent depends on the degree subcutaneous fat deposits, i.e. with increase in the weight of the carcass, the index of the average thickness of the fatback increases by $10.04-13.18 \%$.

\section{Table 4}

The effect of essential oils in the doses of 400, 200, $150 \mathrm{~g} / \mathrm{T}$ and $600,400,200 \mathrm{~g} / \mathrm{T}$ of feed on morphological composition of the carcass $(\mathrm{x} \pm \mathrm{SD}, \mathrm{n}=3)$

\begin{tabular}{lccc}
\hline \multicolumn{1}{c}{ Indicator } & \multicolumn{1}{c}{ Control } & I & \multicolumn{1}{c}{ II } \\
\hline The weight of the carcass, $\mathrm{kg}$ & $74.30 \pm 1.55$ & $78.61 \pm 2.05$ & $81.63 \pm 1.57^{*}$ \\
The muscle tissue, $\mathrm{kg}$ & $57.05 \pm 0.45$ & $60.98 \pm 0.08^{* *}$ & $63.08 \pm 0.19^{* * *}$ \\
Adipose tissue, $\mathrm{kg}$ & $9.56 \pm 0.13$ & $10.02 \pm 0.32$ & $10.66 \pm 0.43^{*}$ \\
Bones and tendons, $\mathrm{kg}$ & $7.69 \pm 0.07$ & $7.63 \pm 0.55$ & $7.89 \pm 0.05$ \\
Muscle tissue, $\%$ & $76.78 \pm 1.05$ & $77.57 \pm 5.87$ & $77.27 \pm 1.22$ \\
Adipose tissue, \% & $12.86 \pm 0.34$ & $12.72 \pm 2.18$ & $13.06 \pm 0.18$ \\
Bones and endons, \% & $10.36 \pm 0.21$ & $9.71 \pm 0.07^{*}$ & $9.67 \pm 0.92$ \\
\hline
\end{tabular}

Note: see Table 2.

In animals of the second and the third groups, the amount of muscle tissue was higher by $3.93-6.03 \mathrm{~kg}(\mathrm{P}<0.001-0.01)$ compared with the control indicator. Content of the adipose tissue increased accordingly by $0.44 \mathrm{~kg}$ on the second and $1.1 \mathrm{~kg}(\mathrm{P}<0.05)$ in the third group. The amount of tendons and bones exceeded the control indicator much less - by $0.2 \mathrm{~kg}$ in the third group. According to the output of the carcass parts, no significant difference was observed. We determined tendency to increase in the output of the muscle tissues in the carcasses of pigs of the experimental groups by $0.49-0.79 \%$ and adipose tissue by $0.20 \%$ in the third group, with a decrease in bone tissue - by $0.65 \%(\mathrm{P}<0.05)$.

It was found that feeding with PVMS Efiprot increased the protein content in the meat of the II and III groups of pigs by $1.39 \%(\mathrm{P}<0.05)$ and $1.67 \%(\mathrm{P}<0.001)$, compared with the control sample (Table 5). The use of the feed factor increased the amount of fat in the meat of the II group by $27.83 \%(\mathrm{P}<0.001)$, and in the III group decreased by $14.4 \%$ 
$(\mathrm{P}<0.001)$, compared with the control group. The ash level in the examined meat of pigs that consumed PVMS was higher in the II group by $3.10 \%$, in III group $38.9 \%(\mathrm{P}<0.001)$ compared with the control.

Table 5

The effect of essential oils in the doses of $400,200,150 \mathrm{~g} / \mathrm{T}$ and $600,400,200 \mathrm{~g} / \mathrm{T}$ of feed on chemical composition of meat $(\%, \mathrm{x} \pm \mathrm{SD}, \mathrm{n}=3)$

\begin{tabular}{lccc}
\hline \multicolumn{1}{c}{ Indicator } & Control & I & II \\
\hline Dry matter, \% & $92.83 \pm 1.04$ & $91.24 \pm 0.94$ & $92.64 \pm 0.45$ \\
Protein, \% & $70.66 \pm 0.14$ & $71.64 \pm 0.21^{*}$ & $71.83 \pm 0.17^{* *}$ \\
Fat, \% & $9.75 \pm 0.07$ & $12.42 \pm 0.07^{* * *}$ & $8.39 \pm 0.14^{* * *}$ \\
Ash, \% & $4.19 \pm 0.04$ & $4.32 \pm 0.03$ & $5.78 \pm 0.06^{* * *}$ \\
Calcium, \% & $0.164 \pm 0.040$ & $0.167 \pm 0.042$ & $0.198 \pm 0.013$ \\
Phosphorus, \% & $1.99 \pm 0.01$ & $1.96 \pm 0.04$ & $1.93 \pm 0.04$ \\
\hline
\end{tabular}

Note: see Table 2.

\section{Table 6}

The effect of essential oils in the doses of 400,200,150 g/T and $600,400,200 \mathrm{~g} / \mathrm{T}$ of feed on quality indicators of the longest back muscle $(\mathrm{x} \pm \mathrm{SD}, \mathrm{n}=3)$

\begin{tabular}{lccc}
\hline \multicolumn{1}{c}{ Indicator } & \multicolumn{1}{c}{ Control } & I & \multicolumn{1}{c}{ II } \\
\hline Total moisture, $\%$ & $70.09 \pm 3.21$ & $69.24 \pm 1.55$ & $67.49 \pm 0.32$ \\
Free, \% & $19.56 \pm 0.15$ & $18.37 \pm 0.07^{* * *}$ & $17.32 \pm 0.12^{* *}$ \\
Bound, \% & $50.53 \pm 0.71$ & $50.87 \pm 0.50$ & $50.17 \pm 0.50$ \\
Dry matter, \% & $29.91 \pm 0.16$ & $30.76 \pm 0.21^{*}$ & $32.51 \pm 0.40^{* *}$ \\
$\mathrm{pH}$ & $6.03 \pm 0.04$ & $5.96 \pm 0.02$ & $5.99 \pm 0.07$ \\
Colour intensity, E100 & $8.53 \pm 0.02$ & $9.16 \pm 0.08^{* * *}$ & $9.83 \pm 0.05^{* * *}$ \\
Protein, \% & $19.30 \pm 0.09$ & $19.58 \pm 0.37$ & $21.98 \pm 0.06^{* * *}$ \\
Fat,\% & $6.82 \pm 0.19$ & $7.13 \pm 0.16$ & $7.75 \pm 0.14^{*}$ \\
\hline
\end{tabular}

Note: see Table 2.

Laboratory study of the longest back muscle showed that the level of the general moisture in the meat of pigs was lower in the second and third groups by $1.21-3.70 \%$ compared with control (Table 6). The level of free moisture in the experimental groups was significantly lower compared with the control parameter by $6.08-11.45 \%(\mathrm{P}<0.001)$. In addition, action PVMS Efiprot in the muscles of pigs increased the level of bound moisture in the II group by $0.6 \%$, but reduces it in the III group by $0.71 \%$. This may indicate an increase in the juiciness of the muscle fibers. Under the influence of different doses of feed additives, the indicators of acidity, colour intensity and tenderness of pork had no significant changes compared with the control sample. Another important indicator that characterizes the nutritional value of feeds, and affects the productivity is their digestibility, i.e. the property of complex organic substances of feed to be digested in the digestive tract into simple compounds.

Studies on determining the consumption of PVMS Efiprot showed that the animals better absorbed the nutrients from feed during the balance experiment than the control group (Table 7).

Table 7

The effect of essential oils in the doses of 400, 200, $150 \mathrm{~g} / \mathrm{T}$ and $600,400,200 \mathrm{~g} / \mathrm{T}$ of feed on the coefficients of digestibility of nutritive substances $(x \pm S D, n=3)$

\begin{tabular}{llll}
\hline \multicolumn{1}{c}{ Indicator } & \multicolumn{1}{c}{ Control } & \multicolumn{1}{c}{ I } & II \\
\hline Dry matter, \% & $84.21 \pm 0.07$ & $85.43 \pm 0.03^{* * *}$ & $85.91 \pm 0.07^{* * *}$ \\
Organic matter, \% & $85.96 \pm 0.08$ & $86.62 \pm 0.07^{* *}$ & $87.21 \pm 0.05^{* * *}$ \\
Crude protein, \% & $71.25 \pm 0.04$ & $74.12 \pm 0.13^{* * *}$ & $75.22 \pm 0.03^{* * *}$ \\
Crude fat, \% & $59.47 \pm 0.04$ & $62.89 \pm 0.07^{* * *}$ & $61.34 \pm 0.54^{*}$ \\
Crude fiber, \% & $33.64 \pm 0.05$ & $35.05 \pm 0.05^{* * *}$ & $38.67 \pm 0.05^{* * *}$ \\
Crude ash, \% & $55.35 \pm 0.03$ & $56.72 \pm 0.03^{* * *}$ & $57.55 \pm 0.05^{* * *}$ \\
Nes, \% & $89.27 \pm 0.07$ & $92.63 \pm 0.07^{* * *}$ & $93.80 \pm 0.12^{* * *}$ \\
\hline
\end{tabular}

Note: see Table 2 .

In particular, the levels of digestible dry and organic matters increased in the II and III group by $1.44(\mathrm{P}<0.001)$ and $2.01 \%(\mathrm{P}<0.001), 0.77$ $(\mathrm{P}<0.01)$ and $1.45 \%(\mathrm{P}<0.001)$ compared with the control. The coefficients of digestibility of protein in both experimental groups were 4.02 $(\mathrm{P}<0.001)$ and $5.57 \%(\mathrm{P}<0.001)$ higher, and digestibility of crude fat $5.75(\mathrm{P}<0.001)$ and $3.10 \%(\mathrm{P}<0.05)$ higher, compared with the control. The data show that feeding with a new feed factor improves digestibility poorly soluble carbohydrates by $4.19 \%(\mathrm{P}<0.001)$ and $14.90 \%(\mathrm{P}<$ 0.001 ), compared with the control, which in turn increases the efficiency of feed on performance. The coefficient of digestibility of crude ash and nitrogen-free extractives increased by $2.47 \%(\mathrm{P}<0.001)$ and $3.97 \%(\mathrm{P}<$ $0.001), 3.76 \%(\mathrm{P}<0.001)$ and $5.07 \%(\mathrm{P}<0.001)$ compared with control. Thus, all the digestible nutrients of the studied diet, enter the blood and lymph in the process of digestion.

\section{Discussion}

According to the literature sources (Windisch et al., 2008, Franz \& Novak, 2009; Randrianarivelo et al., 2010; Gong et al., 2013), plant components (essential oils) are complex mixtures of aromatic volatile and oily compounds that are produced by living organisms and are isolated only physically (pressing and distillation) from the whole plant or part of a plant of known taxonomic origin. Also, some studies report that essential oils are natural bioactive compounds obtained from plants and have a positive effect on the growth and health of animals (Puvača et al., 2013).

Because of their antimicrobial, anti-inflammatory and antioxidant properties, essential oils are considered less toxic and are used as a modern alternative to feed antibiotics ( $\mathrm{Li}$ et al., 2012; Gong et al., 2014). During the conducted study on the effect of essential oils on the investigated parameters, there were observed $0.28 \mathrm{EFU}$, or $6.92 \%$, better consumption and assimilation of feed, as well as increase in average daily weight gain by $4.1 \%$ and $7.1 \%$ compared to control; the level of digestibility of dry and organic substances in the second and third experimental groups has significantly increased by $1.44 \%$ and $2.01 \%$ and $0.77-1.45 \%$, as well as digestible protein by $4.02-5.57 \%$, and digestibility of crude fat - was higher by $3.10-5.75 \%$ compared with the control. Similar indicators were observed in studies of foreign scientists (Franz et al., 2010; Chitprasert and Sutaphanit, 2014; Zeng et al., 2015), who, during the experiment, observed contradictory parameters of improved consumption of food supplemented with essential oils, which ranged $9 \%$ to $13 \%$. According to the authors and our own research (Table 2) on the use of feed additives, the combined use of different antibiotic alternatives had a better effect on productivity and health of weaned pigs compared to their compounds alone in the diet (Zeng et al., 2015; Walia et al., 2017). Also, according to the authors (Bartoš et al., 2016; Lan et al., 2016; Clarke et al., 2018; Xuet al., 2018), young pigs that were fed with essential oils had an increased average daily weight gain, average daily feed intake and the growth rate, rather than those that were fed with low-nutrient diets. There was also higher general absorption of dry matter of calcium, phosphorus, crude protein and gross energy in the tract of pigs, compared with diets having low nutrient density $(\mathrm{P}<0.05)$. The actual digestibility of nitrogen and amino acids was improved $(\mathrm{P}<0.05)$ as a result of addition of essential oils and feeding normalized with nutrient density. Increased digestibility of most amino acids, except threonine, valine, methionine, proline, glycine, alanine, cystine, was increased $(\mathrm{P}<0.05)$ at feeding balanced with nutrient density. In addition, the dietary supplement also had a significant positive effect on the digestibility of some amino acids $(\mathrm{P}<0.05)$, including isoleucine, leucine, lysine, arginine, aspartic acid, serine and tyrosine.

\section{Conclusions}

According to the results of the study, it was found that the use of the protein-vitamin-mineral supplement Efiprot in the diets of young pigs with essential oils in the amount of $150 \mathrm{~g} / \mathrm{T}$ of feed helped to increase the average daily weight gain by $33 \mathrm{~g}(4.1 \%)$. Also it reduced the expenditure of feed per $1 \mathrm{~kg}$ of increment $0.16 \mathrm{EFU}$, or $3.95 \%$, at the fed dose of essential oils equaling $200 \mathrm{~g} / \mathrm{T}$ of feed in the PVMS, the average daily weight gains tended to increase by $58 \mathrm{~g}(7.1 \%)$, while saving feed by $0.28 \mathrm{EFU}$, or $6.92 \%$. Using novel PVMS Efiprot in feeding young pigs, which contains products of plant processing (essential oils), led to the positive productive effects: increases in the slaughter weight by 4.82 and $8.37 \mathrm{~kg}$, slaughter yield by $4.33 \%$ and $5.46 \%$, carcass weight by $5.80 \%$ and $9.86 \%$, and carcass yield by $4.86 \%$ and $6.08 \%$ compared with the control. The use of a new feed additive in the diets of the animals of II and III groups increased the amount of muscle tissue by $3.93-6.03 \mathrm{~kg}(\mathrm{P}<$ $0.001-0.01)$ and the yield of muscle tissue in pig carcasses of the experi- 
mental groups by $0.79-0.49 \%$ compared with the control. The content of adipose tissue increased respectively by 0.44 and $1.10 \mathrm{~kg}(\mathrm{P}<0.05)$ in the second and third groups, while the bone tissue decreased by $0.65-0.69 \%$, compared to control. Between the groups, there was no significant difference in the yield of the carcass components. Feeding young pigs with PVMS Efiprot and essential oils caused increase in the digestibility of all nutrients in the diet: the coefficient of digestibility of dry and organic matter increased in the second and third experimental groups by $1.44 \%$ and $2.01 \%, 0.77-1.45 \%$, protein digestibility was higher by $4.02-5.57 \%$, and the digestibility of crude fat - by $5.75-3.10 \%$ compared with the control. The level of digestibility of poorly soluble carbohydrates was higher by $4.19-14.90 \%$, compared with the control indicator, which in turn increased the feed efficiency in the productivity. The digestibility ratio of crude ash and nitrogen-free extractives increased by $2.47-3.97 \%$ and $3.76-5.07 \%$, as compared with the control.

\section{References}

Babkov, Y. I. (2016). Produktyvni jakosti gibrydnyh porosjat na doroshhuvanni za vykorystannja betajinu [The productive characteristics of hybrid piglets at growing when using betaine]. Zbimyk Naukovyh Prac' Vinnyc'kogo Nacional'nogo Agramogo Universytetu, 3, 11-17 (in Ukrainian).

Bartoš, P., Dolan, A., Smutný, L., Šístková, M., Celjak, I., Šoch, M., \& Havelka. Z. (2016). Effects of phytogenic feed additives on growth performance and on ammonia and greenhouse gases emissions in growing-finishing pigs. Animal Feed Science and Technology, 212, 143-148.

Begma, N. A., \& Mikityuk, V. V. (2011). Produktyvnist' svynomatok za vkljuchennja v kombikormy netradycijnyh protejinovyh komponentiv [Productivity of sows when mixed fodders are supplemented with untraditional protein components]. Zbirnyk Naukovyh Prac' Vinnyc'kogo Nacional'nogo Agramogo Universytetu, 49, 12-17 (in Ukrainian).

Bilyavtseva, V. V. (2016). Peretravlennja pozhyvnyh rechovyn racionu svynej pry zgodovuvanni BVMD "Enervik" $\mathrm{z}$ karnitynom [Digestion of nutrients in pig diets when fed PVMS with carnitine]. Kormy i Kormovyrobnyctvo, 82, 233 239 (in Ukrainian).

Chitprasert, P., \& Sutaphanit, P. (2014). Holy basil (Ocimum sanctum Linn.) Essential oil delivery to swine gastrointestinal tract using gelatin microcapsules coated with aluminum carboxymethyl cellulose and beeswax. Journal of Agricultural and Food Chemistry, 62(52), 12641-12648.

Clarke, L. C., Duffy, S. K., Rajauria, G., \& O’Doherty, J. V. (2018). Growth performance, nutrient digestibility and carcass characteristics of finisher pigs offered either a by-product or cereal based diet at two different concentrations of net energy. Animal Feed Science and Technology, 242, 77-85.

Franz, C., Baser, K., Husnu, C., \& Windisch, W. (2010). Essential oils and aromatic plants in animal feeding - A European perspective. Flavour and Fragrance Journal, 25, 327-340.

Franz, C. M., \& Novak, J. (2010). Sources of essential oils. Science, Technology, and Applications. Boca Raton, FL. Pp. 39-81.

Gong, J., Yin, F., Hou, Y., \& Yin, Y. (2014). Chinese herbs as alternatives to antibiotics in feed for swine and poultry production: Potential and challenges in application. Canadian Journal of Animal Science, 94, 223-241.

Ibatullin, I. I., Melnichuk, D. O., \& Bogdanov, G. O. (2007). Godivlja sil's'kogospodars'kyh tvaryn [Feeding farm animals]. Vinnycja (in Ukrainian).

Ibatullin, I. I., Melnyk, Y. F., Otchenashko, V. V., Sychev, M. Y., Krivenok, M. Y., Chigrin, A. I., Kondratyuk, V. M., Ilchuk, I. I., Umanets, D. P., Yatsenko, O. V., Balanchuk, I. M., Golubev, M. I., Kononenko, V. K., Stolyuk, V. D., \& Panasenko, Y. O. (2015). Praktykum z godivli sil's'kogospodars'kyh tvaryn [Workshop on feeding farm animals]. Ahrarna Nauka, Kyiv (in Ukrainian).
Kucheryavy, V. P., Boychuk, V. M., \& Krivonos, G. P. (2013). Produktyvnist' molodnjaku svynej pry zgodovuvanni Probiolaktu [Productivity of young pigs when fed prebiolact]. Zbirnyk Naukovyh Prac' Vinnyc'kogo Nacional'nogo Agrarnogo Universytetu, 72, 27-32 (in Ukrainian).

Kuzmenko, L. M., Vyslanko, O. O., Bankovskaya, I. B., Zinoviev, S. G., \& Martyniuk, I. O. (2011). Efektyvnist' vykorystannja novogo preparatu - pidkysljuvacha kormiv iz vmistom helatnyh spoluk mikroelementiv - u godivli molodnjaku svynej [The effectiveness of the use of a new drug - feed acidifier containing chelated compounds of trace elements - in the feeding of young pigs]. Visnyk Poltavs'koji Derzhavnoji Agrarnoji Akademiji, 4, 81-85 (in Ukrainian).

Kuzmenko, O. A., \& Bomko, V. S. (2009). Peretravnist' pozhyvnyh rechovyn ta obmin azotu u molodnjaku svynej na vidgodivli za riznyh doz Bio-Mosu v kombikormi [Digestibility of nutrients and nitrogen metabolism in young fattening pigs at different doses of Bio-Moss in feed]. Agrarni Visti, 2, 7-9 (in Ukrainian).

Lan, R. X., Li, T. S., \& Kim, I. H. (2016). Effects of essential oils supplementation in different nutrient densities on growth performance, nutrient digestibility, blood characteristics and fecal microbial shedding in weaning pigs. Animal Feed Science and Technology, 214, 77-85.

Li, P., Piao, X., Ru, Y., Han, X., Xue, L., \& Zhang, H. (2012). Effects of adding essential oil to the diet of weaned pigs on performance, nutrient utilization, immune response and intestinal health. Asian-Australasian Journal of Animal Sciences, 25(11), 1617-1626.

Povoznikov, M. G., Mazurenko, M. O., \& Gucol, A. V. (2003). Metody ocinky vgodovanosti m'jasnoji hudoby ta vyznachennja jakosti m'jasa [Methods for assessing the fattening of beef cattle and determining the quality of meat]. Kam'janec'-Podil's'kyj (in Ukrainian).

Puvaca, N., Stanacev, V., Glamocic, D., Levic, J., Peric, L., \& Milić, D. (2013). Beneficial effects of phytoadditives in broiler nutrition. World's Poultry Science Journal, 69, 27-34.

Randrianarivelo, R., Danthu, P., Benoit, C., Ruez, P., Raherimandimby, M., \& Sarter, S. (2010). Novel alternative to antibiotics in shrimp hatchery: Effects of the essential oil of Cinnamosma fragrans on survival and bacterial concentration of Penaeus monodon larvae. Journal of Applied Microbiology, 109(2), 642-650.

Steiner, T., \& Lokhov, V. (2011). Essential oils in the diets of fattening pigs - another secret of your success. Profits Pig Farming, 4, 58-60.

Svezhentsov, A. I., Gorlach, S. A., \& Martinyak, S. V. (2008). Kombikormy, premiksy, PVMS dlya tvaryn ta ptytsi [Compound feeds, premixes, PVMS for animals and poultry]. Dnipropetrovs'k (in Ukrainian).

Velichko, I. M., Kulik, M. F., \& Khimich, V. V. (2004). Povnocinni kombikormy osnova efektyvnogo vedennja galuzi tvarynnyctva [Full value mixed fodders as a basis of effective development of cattle breeding industry]. Kormy i Kormovyrobnyctvo, 54, 177-180 (in Ukrainian).

Vuhliar, V. S. (2020). The use of medicinal plants that contain essential oils in the feeding of farm animals. Slovak International Scientific Journal, 41(2), 3-8.

Walia, K., Argüello, H., Lynch, H., Leonard, F. C., Grant, J., Yearsley, D., Kelly, S., Duffy, G., Gardiner, G. E., \& Lawlor, P. G. (2017). Effect of strategic administration of an encapsulated blend of formic acid, citric acid, and essential oils on Salmonella carriage, seroprevalence, and growth of finishing pigs. Preventive Veterinary Medicine, 137, 28-35.

Wei, H. K., Wang, J., Cheng, C., Jin, L. Z., \& Peng, J. (2020). Application of plant essential oils in pig diets. Feed Additives. Academic, 227-237.

Windisch, W., Schedle, K., Plitzner, C., \& Kroismayr, A. (2008). Use of phytogenic products as feed additives for swine and poultry. Journal of Animal Science, 86, 140-148.

Xu, Y. T., Liu, L., Long, S. F., Pan, L., \& Piao, X. S. (2018). Effect of organic acids and essential oils on performance, intestinal health and digestive enzyme activities of weaned pigs. Animal Feed Science and Technology, 235, 110-119.

Zeng, Z., Xu, X., Zhang, Q., Li, P., Zhao, P., Li, Q., Liu, J. \& Piao, X. (2015). Effects of essential oil supplementation of a low-energy diet on performance, intestinal morphology and microflora, immune properties and antioxidant activities in weaned pigs. Animal Science Journal, 86, 279-285. 